\title{
Pulmonary Immunohistochemical Detection of Surfactant Protein A (SP-A) in Fatal Drowning
}

\author{
Enrico De Dominicis $^{1^{*}}$, Giuseppe Santeusanio ${ }^{2}$, Filippo Milano ${ }^{1}$, Luigi Tonino Marsella1 \\ ${ }^{1}$ Department of Biomedicine and Prevention, Medical Faculty of Tor Vergata University, Rome, Italy \\ ${ }^{2}$ Department of Experimental Medicine and Surgery, Medical Faculty of Tor Vergata University, Rome, Italy \\ Email: *e.dedominicis75@gmail.com
}

Received 17 June 2016; accepted 10 July 2016; published 14 July 2016

Copyright (C) 2016 by authors and Scientific Research Publishing Inc.

This work is licensed under the Creative Commons Attribution International License (CC BY). http://creativecommons.org/licenses/by/4.0/

c) (i) Open Access

\begin{abstract}
Drowning still remains one of the most difficult diagnoses in forensic pathology because macroscopic and microscopic autopsy findings are unspecific. An ideal diagnostic marker for drowning still needs to be developed, but some authors have recently studied SP-A as a marker of asphyxiation and drowning. The aim of this study is to compare the histopathological features and the SP-A immunohistochemical expression in lung tissue in the case of drowning with those determined by other causes to discriminate between cadaver submersion and drowning.
\end{abstract}

\section{Keywords}

Drowning, Autopsy, Immunohistochemistry, Surfactant Protein A, Pathology

\section{Introduction}

Many cadavers are extracted from water or found near water, but not all of them have drowned [1]. Drowning still remains one of the most difficult diagnoses in forensic pathology because macroscopic and microscopic autopsy findings are unspecific [2].

Histology and immunohistochemistry are important tools for the forensic study of pulmonary tissue. In some cases, like asphyxia and drowning, they are often the only tools to give a diagnostic indication. An ideal diagnostic marker for drowning still needs to be developed, but some authors have recently studied SP-A as the marker of asphyxiation, drowning and respiratory distress syndrome concluding that SP-A is not fully specific for drowning but is a good marker of alveolar injury [3]-[8]. However, experimental studies have shown an in-

${ }^{*}$ Corresponding author.

How to cite this paper: De Dominicis, E., Santeusanio, G., Milano, F. and Marsella, L.T. (2016) Pulmonary Immunohistochemical Detection of Surfactant Protein A (SP-A) in Fatal Drowning. Forensic Medicine and Anatomy Research, 4, 33-36.

http://dx.doi.org/10.4236/fmar.2016.43006 
crease of SP-A expression in asphyxia, suggesting its use as a marker [9]. SP-A is the most abundant surfactant protein produced by alveolar type II cells; its function is to minimize surface tension in the alveolar space, so a type II cells damage causes an alveolar collapse [10].

The aim of this study is to compare the histopathological features and the SP-A expression in lung tissue in the case of drowning with those determined by other causes, like traumas, gunshots and cardiovascular disease. This is with the purpose to deal with the difficult problem of discriminate between cadaver submersion and drowning.

\section{Materials and Methods}

We studied 72 cadavers selected from medico-legal autopsies performed in the Institute of Legal Medicine of the University of Rome "Tor Vergata" from the August of 2013 to the October of 2015, with the approval of the Ethics Committee of the Institute of Legal Medicine of the same University.

Cases were classified into two groups: drowning $(n=21)$ and other causes $(n=51)$ including multiple trauma $(n=11)$, gunshot $(n=6)$ and cardiovascular disease $(n=34)$. During each autopsy, lung tissue was collected from each lobe of both lungs. Specimens were fixed in $10 \%$ phosphate-buffered formalin and embedded in paraffin. Serial sections of $4 \mu \mathrm{m}$ were prepared for the hematoxylin-eosin (HE) and immunohistochemistry. Our conventional HE staining procedure includes dewaxing, staining and clearing of sections.

Sections for immunohistochemistry were attached on to special electrostatically treated slides, and then they were dewaxed, pretreated with antigen retrieval and incubated with primary antibody. Anti-human SP-A mouse monoclonal antibody PE-10 (Dako Japan, Kyoto) was used at 100-fold dilution with a 30-min incubation at room temperature using a universal streptavidin/biotin immunoperoxidase detection system (OmniTags Kit) and DAB (Shandon/Lipshaw/Immunon, Pittsburgh, PA), subsequently the slides were counterstained with hematoxylin. Finally, the sections were mounted in Canada balm. Staining specificity was checked using negative control slides omitting the primary antibody. A negative control study was made using tissue specimen other than lungs.

Histological findings like congestion, alveolar macrophages, intra-alveolar and interstitial edema, emphysema and hemorrhages have been evaluated in the HE stained sections and classified into three groups: mild $(+)$, moderate $(++)$ and severe $(+++)$.

It was evaluated the SP-A immunostaining with an a linear alveolar surface pattern and with an intra-alveolar granular pattern. The SP-A reactivity was classified into three groups: negative (-), positive $(+)$ and strongly positive (S).

\section{Results}

The confrontation between different groups was made using the chi-square test: the significance was assumed for $\mathrm{p}<0.05$. Sections stained with HE showed congestion, intra-alveolar and interstitial edema in all cases of both groups and were no significant differences in the degree of severity $(\mathrm{p}>0.05)$. In the drowning group emphysema and hemorrhages were more common than those in the control group 85.7\% (18/21) and 90.4\% (19/21) respectively. Conversely, alveolar macrophages showed a smaller presence than in control group.

SP-A immunohistochemistry: the linear pattern of staining was positive $\left(^{+}\right)$only in a small percentage of the drowning group $14.2 \%(3 / 21)$ but it was totally negative in the control group. The granular pattern of SP-A immunostaining was strongly positive (S) in the 85.7\% (p < 0.001) of the drowning group (18/21) (Figure 1 and Figure 2) while it was positive (+) in the $11.7 \%$ of the control group (6/51).

\section{Discussion}

The study of macroscopic and microscopic alterations of cadavers in drowning death is of great importance, but often it is not enough to establish with certainty the cause of death. Immunohistochemistry is a useful tool to provide more information, and sometimes it can be crucial. Since the primary target organ for submersion injury is the lung, many authors have studied immunohistochemical expression of markers on lung tissue. For example, CD68 positive alveolar macrophages rather than increasing, as observed in other violent mechanical asphyxia [11], showed a smaller number in drowned victims compared to other causes of death [12], probably caused by a washing effect of water. This was later confirmed by an Italian study about alveolar macrophages in asphyxia [13] and by our observations. 


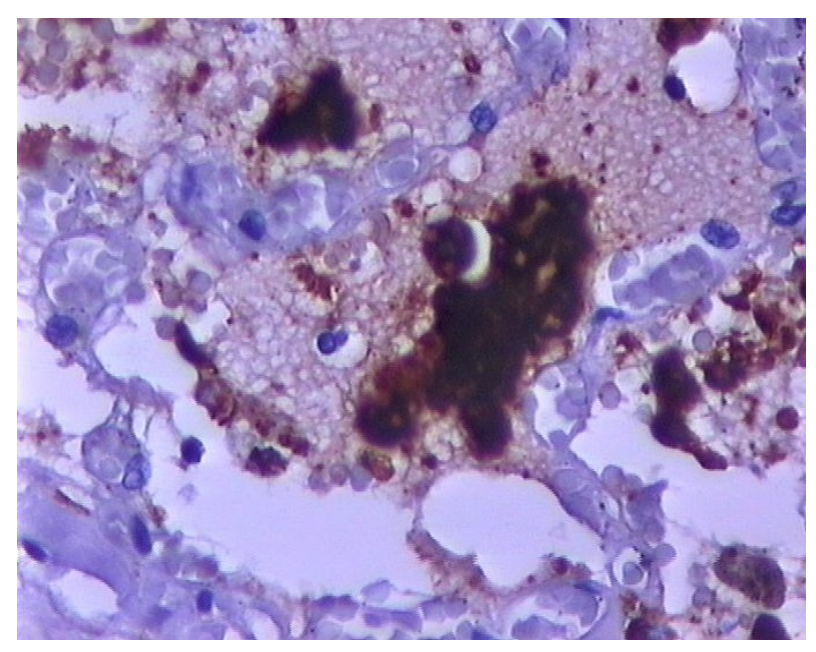

Figure 1. Intra-alveolar intense granular immunostaining of pulmonary SP-A (20x magnification).

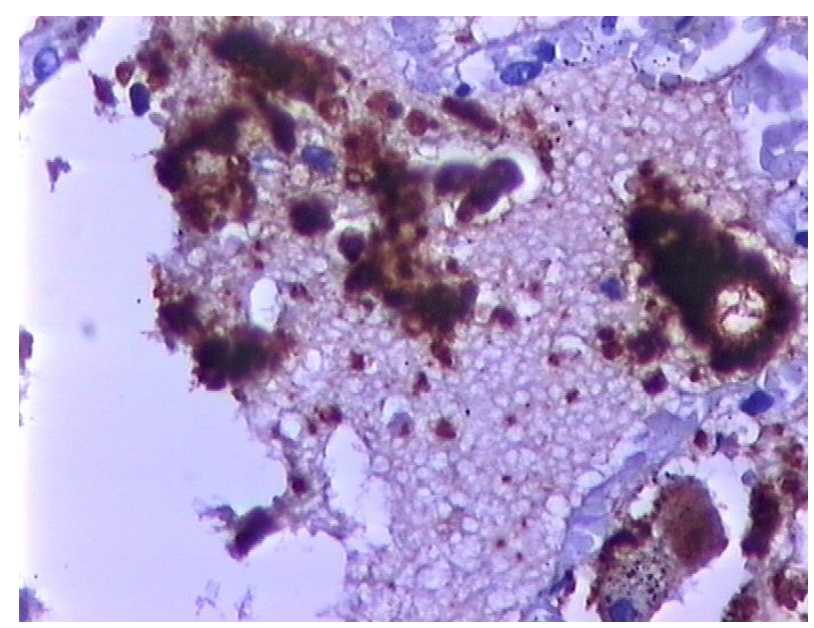

Figure 2. Granular pattern of SP-A immunostaining (20x magnification).

The pathophysiology of drowning includes also disruption and injury of surfactant by massive water inflow [14]. For this reason, many authors investigated the pulmonary surfactant in drowning death [3]-[9]. Lung surfactant is composed by several apoprotein species synthesized by the alveolar type II epithelial cells to reduce the surface tension of the alveolar border [15]. The lipoprotein complex of surfactant is composed by four surfactant proteins (SP) designated SP-A, SP-B, SP-C and SP-D [16]. Experimental studies have showed that pulmonary SP-A increased in hypoxic conditions, suggesting a possible role in the pathophysiology of asphyxiation [17]. In physiologic conditions alveolar distribution of SP-A is restricted to alveolar type II cells and to the inner alveolar surface [18]. According to Zhu et al. [3], there are two different patterns of SP-A immunohistochemical expression: a linear and a granular pattern of staining.

\section{Conclusions}

Our study suggests that alveolar granular distribution of SP-A immunostaining could be of help to clarify the cause of death. Moreover, our study confirms that massive and intense granular SP-A patterns in alveolar space could be associated with drowning, while it is not clear if its expression could help in other fatal asphyxiations.

Although more cases and markers must be studied to reach more reliable conclusions, the SP-A immunostaining could be a reference indicator to distinguish drowning from other causes of death when a body is found on the shore or in the water. 


\section{References}

[1] Saukko, P. and Knight, B. (2016) Knight’s Forensic Pathology. CRC Press, Boca Raton.

[2] Piette, M.H.A. and De Letter, E.A. (2006) Drowning: Still a Difficult Autopsy Diagnosis. Forensic Science International, 163, 1-9. http://dx.doi.org/10.1016/j.forsciint.2004.10.027

[3] Zhu, B.L., Ishida, K., Quan, L., Fujita, M.Q. and Maeda, K. (2000) Immunohistochemistry of Pulmonary Surfactant Apoprotein A in Forensic Autopsy: Reassessment in Relation to the Causes of Death. Forensic Science International, 113, 193-197. http://dx.doi.org/10.1016/S0379-0738(00)00264-4

[4] Zhu, B.L., Ishida, K., Quan, L., Fujita, M.Q. and Maeda, H. (2001) Immunohistochemistry of Pulmonary SurfactantAssociated Protein A in Acute Respiratory Distress Syndrome. Legal Medicine, 3, 134-140. http://dx.doi.org/10.1016/S1344-6223(01)00020-7

[5] Zhu, B.L., Ishida, K., Quan, L., Li, D.R., Taniguchi, M., Fujita, M.Q., Maeda, H. and Tsuji, T. (2002) Pulmonary Immunohistochemistry and Serum Levels of a Surfactant-associated Protein A in Fatal Drowning. Legal Medicine, 4, 1-6. http://dx.doi.org/10.1016/S1344-6223(01)00051-7

[6] Maeda, H., Fujita, M.Q., Zhu, B.L., Ishida, K., Quan, L., Oritani, S. and Taniguchi, M. (2003) Pulmonary SurfactantAssociated Protein A as a Marker of Respiratory Distress in Forensic Pathology: Assessment of the Immunohistochemical and Biochemical Findings. Legal Medicine, 5, S318-S321. http://dx.doi.org/10.1016/S1344-6223(02)00160-8

[7] Perez-Carceles, M.D., Sibon, A., Vizcaya, M.A., Osuna, E., Gomez-Zapata, M., Luna, A. and Martinez-Diaz, F. (2008) Histological Findings and Immunohistochemical Surfactant Protein A (SP-A) Expression in Asphyxia: Its Application in the Diagnosis of Drowning. Histology and Histopathology, 23, 1061-1068.

[8] Stemberga, V., Stifter, S., Cuculic, D., Coklo, M. and Bosnar, A. (2009) Immunohistochemical Surfactant Protein-A Expression: Fatal Drowning vs. Postmortem Immersion. Medical Hypotheses, 72, 413-415. http://dx.doi.org/10.1016/j.mehy.2008.11.024

[9] Zhu, B.L., Ishida, K., Fujita, M.Q. and Maeda, K. (2000) Immunohistochemical Investigation of a Pulmonary Surfactant in Fatal Mechanical Asphyxia. International Journal of Legal Medicine, 113, 268-271. http://dx.doi.org/10.1007/s004149900109

[10] Heinrich, S., Hartl, D. and Griese, M. (2006) Surfactant Protein A-From Genes to Human Lung Disease. Current Medicinal Chemistry, 13, 3239-3252. http://dx.doi.org/10.2174/092986706778773112

[11] Vacchiano, G., D’Armiento, F. and Torino, R. (2001) Is the Appearance of Macrophages in Pulmonary Tissue Related to Time of Asphyxia? Forensic Science International, 115, 9-14. http://dx.doi.org/10.1016/S0379-0738(00)00301-7

[12] Betz, P., Nerlich, A., Penning, R. and Eisenmenger, W. (1993) Alveolar Macrophages and the Diagnosis of Drowning. Forensic Science International, 62, 217-224. http://dx.doi.org/10.1016/0379-0738(93)90210-2

[13] D’Annibale, C. and Tacconi, M.P. (2000) Il Comportamento dei Macrofagi Alveolari Polmonari nelle Morti da Asfissia. Jura Medica, 13, 337-354.

[14] Giammona, S.T. and Modell, J.H. (1967) Drowning by Total Immersion. Effects on Pulmonary Surfactant of Distilled Water, Isotonic Saline, and Sea Water. American Journal of Diseases of Children, 114, 612-616. http://dx.doi.org/10.1001/archpedi.1967.02090270068005

[15] Wright, J.R. (2003) Pulmonary Surfactant: A Front Line of Lung Host Defense. Journal of Clinical Investigation, 111, 1453-1455. http://dx.doi.org/10.1172/JCI200318650

[16] Haagsman, H.P. and Diemel, R.V. (2001) Surfactant-Associated Proteins: Functions and Structural Variation. Comparative Biochemistry and Physiology. Part A, Molecular and Integrative Physiology, 129, 91-108. http://dx.doi.org/10.1016/S1095-6433(01)00308-7

[17] Morita, M., Tabata, N. and Maya, A. (1985) Studies on Asphyxia: On the Changes of the Alveolar Walls of Rats in the Hypoxic State. Forensic Science International, 27, 81-92. http://dx.doi.org/10.1016/0379-0738(85)90170-7

[18] Kuroki, Y., Dempo, K. and Akino, T. (1986) Immunohistochemical Study of Human Pulmonary Surfactant Apoproteins with Monoclonal Antibodies. American Journal of Pathology, 124, 25-33. 


\section{Submit or recommend next manuscript to SCIRP and we will provide best service for you:}

Accepting pre-submission inquiries through Email, Facebook, LinkedIn, Twitter, etc.

A wide selection of journals (inclusive of 9 subjects, more than 200 journals)

Providing 24-hour high-quality service

User-friendly online submission system

Fair and swift peer-review system

Efficient typesetting and proofreading procedure

Display of the result of downloads and visits, as well as the number of cited articles

Maximum dissemination of your research work

Submit your manuscript at: http://papersubmission.scirp.org/ 